UNIWERSYTET

SZCZECIŃSKI

Zeszyty

Naukowe

n r 858
Wspótczesne

Problemy

Ekonomiczne

$n r 11(2015)$

DOI: 10.18276/wpe.2015.11-23

\title{
Sylwia Bas*
}

\section{Neuroekonomia a mózg konsumenta}

Słowa kluczowe: neuroekonomia, eksperyment, elektroencefalografia, funkcjonalny rezonans magnetyczny, manipulacja, zachowania konsumenckie, nabywca, mózg, mózg odruchowy, mózg refleksyjny

Keywords: neuroeconomics, experiment, electroencephalography, functional magnetic resonance, manipulation, consumer behavior, purchaser, brain, reflex brain, rational brain

\section{Wprowadzenie}

Coraz więcej dyscyplin, które dotychczas nie były kojarzone z ekonomią, w dzisiejszej rzeczywistości znajdują zastosowanie $\mathrm{w}$ analizie działań podejmowanych na rynku. Wśród nich można wyróżnić: antropologię, biologię ewolucyjną, psychologię porównawczą, neuropsychologię i neurobiologię. Współdziałanie tak różnych dziedzin pomogło wyodrębnić nowe podejście do badań zachowań i decyzji ekonomicznych. Jest nim neuroekonomia.

Neuroekonomia jest stosunkowo nową dziedziną wiedzy zapoczątkowaną w latach dziewięćdziesiątych. Pozwala zrozumieć, jakie procesy zachodzą w mózgu w trakcie lub jeszcze przed podjęciem decyzji. Najprościej można ją określić jako multidyscyplinarne podejście do badania neurofizjologicznych podstaw wyborów ekonomicznych dokonywanych przez ludzi ${ }^{1}$.

\section{Metody obrazowania mózgu}

Neuroekonomia posługuje się wieloma standardowymi metodami diagnostycznymi, ale tym, co odróżnia ją od innych dziedzin, na przykład ekonomii eksperymentalnej czy

\footnotetext{
* Magister Sylwia Bas jest doktorantką na Wydziale Wydział Zarządzania i Ekonomiki Usług (Katedra Organizacji i Zarządzania) Uniwersytetu Szczecińskiego. E-mail: sylwia.bas@o2.pl.

1 T. Zaleśkiewicz, Psychologia ekonomiczna, Wydawnictwo Naukowe PWN, Warszawa 2011, s. 37.
} 
psychologii, jest wykorzystanie specyficznych metod pomiarowych. Korzysta między innymi z rezonansu magnetycznego, elektroencefalografii, tomografii komputerowej czy psychogalwanometru. Dwa pierwsze urządzania są najczęściej wykorzystywane przy monitorowaniu mózgu.

Funkcjonalny rezonans magnetyczny jest wąską tubą otoczoną potężnymi magnesami. Poprzez uruchomienie magnesów tworzą się pola elektryczne, które za pomocą komputerowej technologii obrazowania zostają przetworzone na obrazy wewnętrznych struktur ciała. Rezonans mierzy wzrost poziomu tlenu we krwi przepływającej przez mózg. Dzięki temu można się dowiedzieć, kiedy wzrasta aktywność określonego obszaru mózgu. W tracie wzmożonej aktywności neurologicznej mózg potrzebuje więcej natlenionej krwi, co jest rejestrowane przez to urządzenie 2 .

Z kolei elektroencefalograf wykorzystuje lekki czepek gęsto pokryty czujnikami, który umieszcza się na czaszce badanego. Czujniki potrafią wychwycić ulotne sygnały elektryczne generowane przez aktywność fal mózgowych. Jeden czujnik jest w stanie wychwycić do 2 tysięcy odczytów na sekundę

Opisane metody są bardzo skuteczne, zwłaszcza wtedy, gdy badane są automatyczne procesy psychiczne determinujące zachowania ekonomiczne, do których świadomy umysł nie ma dostępu. W takich sytuacjach osoba badana poprzez standardowe badania typu wywiad czy kwestionariusz ankietowy nie jest w stanie udzielić prawidłowych odpowiedzi odzwierciedlających obecną sytuację. Ma to miejsce na przykład przy rozstrzyganiu, czy określona decyzja finansowa podejmowana jest pod wpływem racjonalnej analizy, czy też emocji ${ }^{4}$.

\section{Dwa mózgi}

Żeby w pełni wykorzystać możliwości dowolnego narzędzia czy urządzenia, należy dobrze poznać podstawowe zasady jego działania. Zatem, aby dobrze zrozumieć możliwości funkcjonowania ludzkiego mózgu i podejmowanych przez niego decyzji, trzeba dogłębnie poznać jego struktury.

Nie od dziś wiadomo, że obydwie półkule odpowiadają za inne zadnia. W dużym uproszczeniu lewa półkula odpowiedzialna jest za język i zdolności matematyczne, a prawa za kreatywność i intuicję. Podział może być jeszcze inny - na mózg odruchowy i mózg refleksyjny.

\footnotetext{
A.K. Pradeep, Mózg na zakupach, Helion, Gliwice 2011, s. 24.

Tamże, s. 23.

T. Zaleśkiewicz, dz. cyt., s. 38.
} 
Ośrodki pierwszego z nich - mózgu odruchowego - zlokalizowane są pod korą mózgową. Mimo że kora mózgowa uczestniczy w funkcjonowaniu systemu emocjonalnego, większość procesów o charakterze odruchowym zachodzi wewnątrz, w jądrach podstawnych oraz w układzie limbicznym ${ }^{5}$. Mózg odruchowy jest kombinacją wielu struktur i procesów, które potrafią różnymi sposobami rozwiązać różnorodne problemy. Wszystko to odbywa się automatycznie, szybko i poza ludzką świadomością. Reakcja systemu odruchowego już ustaje, zanim świadomość zorientuje się, że jakikolwiek bodziec się pojawit' . Masa ludzkiego mózgu zwykle stanowi niespełna $2 \%$ ogólnej masy ciała. W stanie spoczynku zużywa około $20 \%$ przyswajanego tlenu i spalanych kalorii7. Mózg nie jest w stanie kontrolować wszystkiego, co się dzieje wokół, ponieważ doprowadziłoby to do przeciążenia. Zatem ta część mózgu próbuje automatycznie unikać kar i dążyć do nagród.

Natomiast jeżeli chodzi o mózg refleksyjny, to w tym przypadku za jego funkcjonowanie odpowiedzialna jest kora przedczołowa i kora ciemieniowa. Gdy mózg odruchowy nie radzi sobie w pewnych sytuacjach, zadania są dla niego zbyt trudne, wówczas działanie podejmuje mózg refleksyjny. Ta część jest bardziej racjonalna, zdolna do przetwarzania emocji w złożonych problemach.

Mogłoby się wydawać, że jeżeli chodzi o pieniądze, to ludzie starają się być bardziej racjonalni, lecz w rzeczywistości okazuje się, że częściej jednak uaktywniają się systemy mózgu odruchowego ${ }^{8}$.

\section{Mózg a zakupy}

Neuroekonomia jako interdyscyplinarna dziedzina wiedzy rozpatruje również codzienne zachowania ekonomiczne związane na przykład z kupnem danego produktu.

Dzięki zaawansowanym badaniom z wykorzystaniem urządzeń służących do pomiaru fal mózgowych można głębiej analizować wybory dokonywane przez konsumentów. W tym celu został przeprowadzony eksperyment, którego zadaniem było sprawdzenie, czy można przewidywać wybory dokonywane przez konsumentów na podstawie analizy zmian aktywności różnych obszarów mózgu. Głównym celem badania było znalezienie odpowiedzi na pytanie, w jaki sposób mózg konsumenta reaguje na zmiany cen produktów.

W kontekście ekonomicznym akt kupna-sprzedaży jest wymianą, gdzie sprzedający oferuje dane dobro, a nabywca płaci za nie określoną cenę. Jednak różne mogą być reakcje

\footnotetext{
J. Zweig, Twój mózg, twoje pieniqdze, MT Biznes, Warszawa 2008, s. 29.

Tamże, s. 30.

Tamże, s. 31.

Tamże, s. 34-35.
} 
na daną cenę. Jedna ze stron może uznać, że ceny są sprawiedliwe, zaś druga - że mocno zawyżone. Eksperyment miał na celu ujawnienie, co dzieje się w mózgu konsumenta, gdy cena na dany produkt ulegnie zmianie. W jakich sytuacjach będzie skłonny zaakceptować wyższą cenę? Teoria sformułowana przez D. Kahnemana i A. Tversky'ego ${ }^{9}$ opisuje, że ludzie charakteryzują się silną awersją do ponoszenia strat, czyli innymi słowy niechętnie pozbywają się pieniędzy. Na podstawie tej teorii można wywnioskować, że wzrost ceny wywoła właśnie taką sytuację. Tylko teraz nasuwa się kolejne pytanie, czy dodatkowe czynniki wpływające na atrakcyjność produktu przewyższą ową awersję. Na rynku stosowane są rozmaite zabiegi, aby zminimalizować przykre uczucia związane z wydawaniem pieniędzy, na przykład poprzez korzystanie z punktów lojalnościowych czy płacenie kartą kredytową ${ }^{10}$. Konsument ma wrażenie, że nie ponosi kosztów, ponieważ fizycznie nie obraca gotówką.

W eksperymencie nastąpiła symulacja kupowania, gdzie manipulowano ceną oferowanych dóbr. W pierwszej kolejności został przedstawiony produkt, który można nabyć, następnie podano, w jakiej cenie. Trzecia faza dotyczyła podejmowania decyzji, czy konsument zgodzi się, czy też nie na proponowaną ofertę. Ostatnim krokiem była fiksacja przed kolejnym etapem eksperymentu.

Autorzy eksperymentu postawili hipotezę, że na podstawie zmian poziomów aktywacji mózgu będzie można przewidywać, jaką decyzję podejmie badana osoba. W analizie wyników zastosowano metodę regresji logistycznej, gdzie poziomy aktywacji różnych obszarów mózgu były zmiennymi niezależnymi, a wybory dokonywane przez badanego - zmiennymi zależnymi. Wyniki pokazały, że prawdopodobieństwo kupienia oglądanego produktu zwiększał'

a) wzrost aktywności w rejonie jądra półleżącego, co zawsze wiąże się z oczekiwaniem na coś przyjemnego;

b) wzrost aktywności w rejonie przyśrodkowej części kory przedczołowej, który zaangażowany jest w kalkulowanie zysków i strat;

c) spadek aktywacji w rejonie wyspy, która jest aktywna podczas przeżywania czegoś nieprzyjemnego.

Otrzymane dane pokazują, że monitorując reakcje neuronalne, można prognozować decyzje zakupowe dokonywane przez konsumentów. Ustalanie cen przez sprzedawców powinno być sporządzane z rozwagą, ponieważ często wywołują one u nabywców efekt kotwiczenia, co w przyszłości może odbić się na kolejnych zakupach. Konsumenci w dużym stopniu postrzegają akt kupowania jako konieczność stracenia pieniędzy,

\footnotetext{
9 T. Zaleśkiewicz, dz. cyt., s. 444.

10 M. Goszczyńska, M. Górnik-Durose, Psychologiczne uwarunkowania zachowań ekonomicznych, Difin, Warszawa 2010, s. 279.

11 T. Zaleśkiewicz, dz. cyt., s. 443-446.
} 
aby zdobyć to, co jest im potrzebne. Jednak aktywacja systemów mózgu odruchowego i czynniki wpływające na zmysły odbiorcy w miejscu sprzedaży sprawiają, że chłodna kalkulacja podczas zakupów w praktyce rzadko się sprawdza.

\section{Pięć zmysłów}

Wydawać by się mogło, że konsumenci wiedzą, czego chcą, ale 95\% procesów myślowych odbywa się w nieświadomości. Wizerunek sklepu jest jednym z ważniejszych czynników wpływających na decyzje konsumentów. Miła atmosfera w sklepie tworzona nie tylko poprzez właściwą ekspozycję towarów na półkach, ale również dzięki efektownej aranżacji wystroju, wpływa pozytywnie na odczucia klientów. Atmosfera w sklepie jest świadomie budowana w celu wywoływania określonych efektów. To zamierzone działania skierowane na nabywców, budzenie w nich uczuć, które spowodują prawdopodobieństwo zwiększenia zakupów. Wpływa ona również na zmysły odbiorcy: wzrokowe, słuchowe, węchowe, dotykowe i smakowe, za pośrednictwem których nabywca może podjąć określone decyzje.

Badania marketingowe wykazują, że ,aż 83\% przekazów marketingowych skupionych jest na dotarciu do konsumenta poprzez zmysł wzroku. A to oznacza, że na inne zmysły marketingowcy przeznaczają tylko $17 \%$ swoich aktywności. To niesamowite, zważywszy na fakt, że aż 75\% naszych codziennych emocji jest wywołanych tym, co czujemy dzięki zmysłowi węchu. Pod wpływem pozytywnego dźwięku $65 \%$ z nas ma szansę na zmianę nastroju, twierdzi Martin Lindstrom w «Brand sense»»"12.

\section{Wzrok}

Pierwsze z wymienionych bodźców - wizualne - są najsilniejsze. Wzrok pośredniczy w przekazywaniu aż $80 \%$ wszystkich informacji do umysłu. Na podstawie tych danych człowiek jest w stanie podjąc setki drobnych decyzji i orientuje się w swoim otoczeniu.

„Co ciekawe, odbiór bodźców wzrokowych dokonuje się nie na poziomie oczu, lecz na poziomie mózgu"'13. Oczy wyłapują światło i poprawiają ostrość obrazu, lecz to mózg dokonuje interpretacji kolorów, kształtów, które się na ten obraz składają.

Podstawowa czynność, jaką są zakupy, związana jest z postrzeganiem towarów poprzez ich barwy. Każdy kolor ma określoną symbolikę, skojarzenia oraz sposób oddziaływania na odbiorcę, które można wykorzystać w sklepie. Dzięki kolorom można wpłynąć na podświadomość konsumenta w celu wywołania w nich określonych za-

2 A. Kotkowska, Marketing na 5 (zmystów), „Marketing w Praktyce” 2011, nr 7, s. 49.

13 A.K. Pradeep, dz. cyt., s. 50. 
chowań. Odpowiednio dobrany kolor może natychmiast stworzyć nastrój i przywołać ciekawe wspomnienia.

\section{Słuch}

Innymi bodźcami oddziałującymi na klienta w miejscu sprzedaży są bodźce słuchowe. Muzyka w miejscu sprzedaży stała się powszechnym i obowiązującym elementem towarzyszącym przy zakupach. Wywołuje ona emocje, wzmacnia przekaz i wpływa perswazyjnie. Silnie oddziałuje nie tylko na subiektywnie odbierane emocje. Może wpłynąć także na poziom neuroprzekaźników, takich jak serotonina, noradrenalina czy dopamina. Ponadto, może oddziaływać na układ krążenia - na ciśnienie, tętno, wydzielanie potu, jak również na metabolizm, między innymi na poziom cukru we krwi ${ }^{14}$. Badania wykazują, że muzyka ma znaczący wpływ na sprzedaż. Odpowiedni podkład muzyczny może spowodować zwiększenie sprzedaży nawet o 40\%. Dzięki niej można nawiązać bardzo osobisty kontakt z nabywcą. Sam głos ludzki, oddzielony od widoku osoby, ma wyjątkową siłę perswazyjną. $Z$ kolei tempo muzyki wpływa na szybkość poruszania się po sklepie. Wolne tempo muzyki zmniejsza prędkość poruszania się klientów, a szybkie - zwiększa. Amerykański psycholog R.E. Milliman udowodnił, że radosna muzyka poprawia nastrój konsumentów. W sklepach, w których emitowano muzykę rockową, sprzedaż wzrosła o $8 \%$, natomiast tam, gdy grano spokojniejsze rytmy, wówczas wzrosła aż o $38 \%{ }^{15}$.

Okazuje się, że pora dnia również ma znaczenie. W porannych godzinach lepiej stosować dynamiczne, żywe melodie aktywizujące do działania, zaś w południowych zaleca się spokojniejsze rytmy. Natomiast w porach popołudniowych, gdy jest największe natężenie klientów, powinno się nadawać rytmiczne dźwięki sprzyjające szybszym zakupom i zwalnianiu miejsca dla kolejnych klientów.

\section{Zapach}

Kolejnymi bodźcami mającymi swój udział w tworzeniu atmosfery sklepu są zapachy. Zapach to najstarsza forma komunikacji występująca w przyrodzie. Zmysł powonienia najmocniej powiązany jest z częściami mózgu odpowiedzialnymi za emocje. Zapachy są przechowywane dłużej w pamięci w porównaniu do dźwięków i obrazów. To one wpływają na podejmowane decyzje przez klientów.

Według badań stopień przyjemności, jaką odczuwali odbiorcy w ciągu pięciu minut po wejściu do sklepu, pozwalał określić, jak długo w nim pozostaną i ile wydadzą pie-

14 J. Woźniak, Neuromarketing 2.0, Helion, Gliwice 2012, s. 46.

15 J. Kall, Promocja sprzedaży-czyli jak sprzedać więcej, Businessman Press, Warszawa 1995, s. 223. 
niędzy. Ponadto, zapach wydłuża czas przebywania w placówce o $16 \%$. Oddziałuje to nie tylko na reagowanie na bodźce sklepowe, ale także na rzeczywistą sprzedaż ${ }^{16}$.

Wykorzystywanie zapachów w celu oddziaływania na nabywców prowadzi między innymi do ${ }^{17}$ :

a) polepszenia pozytywnego podejścia konsumentów do produktu, usługi czy miejsca;

b) poprawy odczuć i nastroju klientów;

c) bardziej emocjonalnego podejścia i pozytywnej opinii przy wyborze towarów i placówek;

d) skupienia znacznie większej uwagi w porównaniu z bodźcami wizualnymi;

e) wydłużenia czasu spędzanego w sklepie;

f) wzrostu tendencji do zakupów, a tym samym wzrostu sprzedaży;

g) stworzenia atmosfery wpływającej na dobre samopoczucie;

h) osiągnięcia przewagi konkurencyjnej.

Aby zapachy były odbierane przez konsumentów pozytywnie, źródło ich pochodzenia musi być w zasięgu ich wzroku. Negatywnie mogą zostać odebrane, gdy są zbyt intensywne. Przyjemne zapachy ułatwiają wzbudzanie miłych wspomnień, przez co wydłużają czas spędzony w sklepie i zwiększają efektywność zakupów. Ponadto, aby spełniały swoją rolę, muszą być spójne z otoczeniem.

\section{Dotyk i smak}

Bodźce dotykowe i smakowe są istotne przy podejmowaniu decyzji zakupowych, lecz niewiele zostało przeprowadzonych badań na ten temat. Większe prawdopodobieństwo zakupu zachodzi wówczas, gdy klient ma możliwość dotknięcia towaru, jego oglądania, wąchania, a nawet posmakowania przy degustacji produktów ${ }^{18}$.

„Receptory przekazują informacje o bodźcach smakowych do zakończeń włókien nerwowych, skąd za pośrednictwem nerwów czaszkowych impulsy trafiają do ośrodków smaku z pniu mózgu. Stamtąd zostają przekazane do wzgórza oraz do kory mózgu, gdzie zachodzi świadomy odbiór bodźców smakowych"19.

Wszystkie omówione bodźce odgrywają ważną rolę. Gdy konsument ma możliwość bezpośredniego kontaktu z produktem i zidentyfikowania go swoimi zmysłami, wówczas jest większe prawdopodobieństwo zakupu. Atmosfera sklepu zostaje wzbogacona również o swoje funkcje kulturoznawcze i społeczne, ponieważ sprzyja powstawaniu kontaktów międzyludzkich.

16 W. Stasiak, Czas aromamarketingu, ,Marketing w Praktyce” 2005, nr 3, s. 7.

7 L. Witek, Merchandising, C.H. Beck, Warszawa 2007, s. 64.

18 M.R. Solomon, Zachowania i zwyczaje konsumentów, Helion, Gliwice 2006, s. 75.

19 A.K. Pradeep, dz. cyt., s. 57 


\section{Podsumowanie}

Neuroekonomia jest połączeniem ekonomii, psychologii i neurobiologii. Jej część koncentruje się na odkrywaniu neurofizjologicznych podstaw ocen i zachowań konsumenckich. Konsumpcja jest ważna w ekonomii, bowiem zachowania konsumpcyjne należą jednak do jednej z dwóch sfer aktywności ekonomicznej ludzi. Po pierwsze, skierowane są na zaspokajanie potrzeb, a tym samym na wykorzystywanie środków konsumpcji. Nabywanie dóbr przez konsumenta powoduje, że staje się on elementem rynku, który warunkuje jego wzrost gospodarczy. Po drugie, aktywizuje sferę pracy, bowiem tworzy zapotrzebowanie na produkty, a tym samym utrzymuje w ruchu produkcję i napędza jej rozwój.

Od lat ekonomiści różnych szkół teoretycznych poszukiwali odpowiedzi na pytanie, w jaki sposób ludzie, a dokładniej jednostki racjonalne - homo economicus - dokonują wyborów spośród ograniczonej puli dóbr. Porównanie normatywnych modeli ekonomicznych z faktycznymi zachowaniami ludzi mocno odbiegają od teoretycznego homo economicus. Obecnie, wykorzystując nowoczesne metody obrazowania mózgu, można prognozować przyszłe decyzje ekonomiczne, w tym zakupowe, podejmowane przez konsumentów.

Ludzki mózg jest emocjonalny i dobrze wykorzystują to merchandisierzy, trafiając do zmysłów odbiorcy. Większość bodźców trafia do mózgu za pośrednictwem wzroku, ale pozostałe zmysły (słuch, dotyk, węch, smak i zmysł równowagi) również odgrywają istotną rolę w tym względzie. Co sekundę zmysły odbierają około 11 milionów informacji. Świadomy umysł potrafi w najlepszym razie przetworzyć około 40 informacji na sekundę. Wszystkie pozostałe informacje podlegają analizie na poziomie podświadomym. Około 95\% procesów myślowych człowieka ma charakter nieświadomy.

Monitorując reakcje neuronalne konsumentów, można prognozować i zrozumieć, w jaki sposób podejmowane są decyzje zakupowe.

\section{Literatura}

Goszczyńska M., Górnik-Durose M., Psychologiczne uwarunkowania zachowań ekonomicznych, Difin, Warszawa 2010.

Kall J., Promocja sprzedaży - czyli jak sprzedać więcej, Businessman Press, Warszawa 1995.

Kotkowska A., Marketing na 5 (zmystów), „Marketing w Praktyce” 2011, nr 7.

Pradeep A.K., Mózg na zakupach, Helion, Gliwice 2011.

Solomon M.R., Zachowania i zwyczaje konsumentów, Helion, Gliwice 2006.

Stasiak W., Czas aromamarketingu, ,Marketing w Praktyce” 2005, nr 3.

Tyszka T., Psychologia ekonomiczna, GWP, Gdańsk 2004.

Witek L., Merchandising, C.H. Beck, Warszawa 2007. 
Woźniak J., Neuromarketing 2.0, Helion, Gliwice 2012.

Zaleśkiewicz T., Psychologia ekonomiczna, Wydawnictwo Naukowe PWN, Warszawa 2011.

Zweig J., Twój mózg, twoje pieniqdze, MT Biznes, Warszawa 2008.

\section{Streszczenie}

Neuroekonomia jest dziedziną nauki, w której bada się neuronalne korelaty decyzji i ocen ekonomicznych, wykorzystując do tego przede wszystkim takie metody, jak funkcjonalny rezonans magnetyczny czy elektoencefalografię. Część neuroekonomii koncentruje się na odkrywaniu neurofizjologicznych podstaw ocen i zachowań konsumenckich, na przykład w przypadku kupna danego dobra. Aby bliżej zrozumieć decyzje nabywców, należy poznać mechanizmy działania mózgu. Celem analiz jest wyjaśnienie, jakie procesy zachodzą w ludzkim mózgu w trakcie podejmowania decyzji ekonomicznych. Na podstawie uzyskanych wyników można przewidzieć, w jakich sytuacjach konsument podejmie decyzję o kupnie, a kiedy zrezygnuje z oferowanego produktu. Jednak im większa wiedza na ten temat, tym większe ryzyko dla konsumenta, że jego zmysły ulegną manipulacji.

\section{Neuroeconomics and consumer brain}

Neuroeconomics is a field of science which investigates the neural correlates of decisions and economic assessments, using mainly methods such as functional magnetic resonance and electroencephalography. Part of neuroeconomics focuses on discovering the neurophysiological basis of assessments and consumer behavior, for example in case of a purchase of a good. To understand better the decisions of customers, you need to understand the mechanisms of brain. The aim of the analysis is to explain what kind of processes undergo in human brain during making economic decisions. On the basis of these results we can predict in which situations a consumer makes a decision of purchase, and when he resign from buying an offered product. However, the greater the knowledge, the greater the risk for the consumer that his senses will undergo manipulation. 